\title{
GENDER DIFFERENCES IN ENGLISH TEACHERS COMMUNICATION PATTERN AT SMPN 1 PETANGBADUNG REGENCY
}

\author{
I Luh Meiyana Ariss Susanti \\ English Education Department \\ STKIP Agama Hindu Singaraja, Bali, Indonesia \\ meysusanti14@yahoo.com
}

\begin{abstract}
In this study, the researcher would like to investigate the types of reinforcements used by male and female teacher, the frequency of using reinforcements both male and female teacher, and to whom it is usually addressed by each teacher. The concern of this study, there were two subjects chosen, one male and one female English teacher. The data was collected through observation and interview. The result of the study showed that those teachers are the same in using the types of reinforcement; they applied praise and negative reinforcement. In term of frequency of using reinforcement, female teachers applied more often than male teachers. Male and female teacher tended to reinforce them who were active in the classroom without regarding the students' gender. In responding to reinforcement given, mostly students responded by smiling and becoming more active in the following the next lesson. In certain cases, male student showed different responses, particularly when they received negative reinforcement in term of point reducing and withdrawing certain image that they had.
\end{abstract}

Keywords: gender, feedback, and reinforcement. 


\section{INTRODUCTION}

Classroom environment is fully influenced by the teachers and the students. The teacher as a motivator should be able to apply reinforcement as effectively as possible in order to conduct a conducive atmosphere in the classroom. Teacher belongs to the diversity in classroom environment. They are different in education, experience, and also in gender. Male and female educators have their own style in teaching. It caused by gender identity and role that has attached them. In short, gender differences are assumed to carry a great influence to the way they perform in the classroom

Theoretically, gender is not something we are born with and not something we have, but something we perform, something we do (West and Zimmerman, 1987 in Eckert and McConnell 2003: 20). Gender development does not end with childhood or adolescence, gender continue to be transformed as we continue to market place - as we learn to act like secretary, lawyer and also teacher (Eckert and McConnell 2003: 20) Means that, gender differences does not merely concern on being male and female, but also on how person either male and female do something including in job professionalism, and in this case a teacher. Based on the statement above, a profession as a teacher is usually associated with women due to its natural characteristics. Women seek for human connection. Therefore, they tend to use super polite form of language and create positive relationship by using those kinds of language, more than men do. Men are said to be in competition with commitment to teaching. Men are jockeying for position on a hierarchy of competitive accomplishment asymmetrical status. Men, it is said, are generally more aggressive, physically and verbally, and enjoy taking risks. For that reason, men use talk competitively, interrupt and reroute topics to keep their ideas spotlight. These difference characteristics will put them in different view of teaching. Clearly, those natural characteristics will influence the way of male and female teachers in implementing several aspects of teaching and learning activities.

Considering the phenomenon above, it is predicted that gender differences among the teachers also influence the different treatment that they deliver to male and female students. Therefore, the researcher focused this study on how gender differences influence the use of reinforcements, including which types of reinforcement that are usually applied by male and female teachers, how do male and female teachers differ in frequency of addressing reinforcement, and how do male and female English teachers differ in addressing reinforcement, whether male teachers tend to reinforce female students only or vice versa.

The study was conducted in SMPN 1 Petang, Badung Regency. The selection of this school as the setting of the study because SMPN 1 Petang is favorite school in Petang district, Badung Regency and also, this school gives primarily concern on its students' ability in mastering English, besides the researcher find that the English teachers usually employed reinforcement during the process of teaching and learning. These concerns facilitated the researcher to conduct a research in this school.

\section{METHOD \\ Research Design}

The study applied a qualitative research design. Qualitative research defined as a study that investigates the quality of relationships, activities, situation, or materials. In other words, qualitative research involved obtaining a holistic picture of what goes on in a particular situation or setting. The study was conducted in order to find out the types 
of reinforcement that are used by male and female English teacher in SMPN 1 Petang. How male and female English teachers differed in frequency of addressing reinforcement in teaching the students of SMPN 1 Petang, how male and female English teachers differed in addressing reinforcement in teaching students of SMPN 1 Petang are the other focus on this study

\section{Procedure}

This research done by using two common methods, they were field observation and interviews. In field observation, the researcher spent time in observing and recording what was going on in the classroom in the situation under the study, in this case social interaction between the teacher and the students especially in the use of reinforcement, verbal interaction, body expression, and environmental factors that may be occur in the situation. While in the interview session, it was done to collect the data related to how reinforcement influences students' motivation in learning English.

\section{Method of Analysis}

The data that have been collected was analyzed by using Miles and Huberman theory of analyzing data. The steps included data collection, data reduction, data display and conclusion drawing. The process as the following:

a) Data Collection

The first step is data collection. In qualitative research, data collection can be done through observation, interview, and document analysis, while in this research only observation and interview are involved. The observation here takes the form of participatory observation, with the complete participation of the researcher. To record the process of teaching and learning in the classroom, the researcher used tape recorder, notebook, observation sheet, and interview guide.

b) Data Reduction

The procedures of data reduction included organizing the data, identifying emerging theme, categories, and patterns and then testing hypothesis against the data. The data indicating the use of reinforcement and which shows the differences between male and female teacher in using reinforcement is chose to be displayed and analyzed.

c) Data Display

This is a phase in which the data selected is displayed in the form of diagram or chart that provided systematic pattern, classification and interrelation steps based on our focus of the study. In this research, the focused data will be presented in the form of table.

d) Conclusion Drawing

In qualitative research, the conclusion will be drawn continuously throughout the course of a stud 


\section{FINDINGS AND DISCUSSION}

The details about the session of data taking as following:

Table 1. Setting of the study

\begin{tabular}{cccl}
\hline No & Subject & Date / Period & \multicolumn{1}{c}{ Class / Subject } \\
\hline 1 & Male Teacher (T1) & $24^{\text {th }}$ Sept 2014 & VII A1 / Shopping \\
& & $28^{\text {th }}$ Sept 2014 & VII B / Season \\
\hline 2 & Female Teacher (T2) & $25^{\text {h }}$ Sept 2014 & VII A2 / Shopping \\
& & $27^{\text {th }}$ Sept 2014 & VII C / Food and Drink \\
\hline
\end{tabular}

The findings presented include the type of reinforcement, the frequency of using reinforcement, and the way of addressing reinforcement applied by male and female teacher (T1 and T2).

a) Types and Frequency of Reinforcement Used by the Male Teacher (T1)

Positive Reinforcement

Table 2. Types and Frequency of Positive Reinforcement Used by a Male Teacher

\begin{tabular}{|c|c|c|c|}
\hline No & Positive Reinforcement & Codes & $\begin{array}{l}\text { Frequencies of } \\
\text { Occurrence }\end{array}$ \\
\hline 1 & Iya, Ok $(\mathrm{V}-\mathrm{P})$ & 1.1 & 1 \\
\hline 2 & $\operatorname{Good}(\mathrm{V}-\mathrm{P})$ & 1.2 & 1 \\
\hline 3 & Ok $(\mathrm{V}-\mathrm{P})$ & $1.3,1.5,1.7,4.5$ & 4 \\
\hline 4 & Very $\operatorname{good}(\mathrm{V}-\mathrm{P})$ & 1.9 & 1 \\
\hline 5 & Ya... $(\mathrm{V}-\mathrm{P})$ & $4.1,4.2,4.3$ & 3 \\
\hline 6 & It's a good question $(\mathrm{V}-\mathrm{P})$ & 4.6 & 1 \\
\hline \multicolumn{4}{|c|}{ Total number of verbal praise 11} \\
\hline 7 & $\begin{array}{l}\text { Approaching the students }(\mathrm{N} \\
-\mathrm{V})\end{array}$ & 1.1 & 1 \\
\hline 8 & Giving applause $(\mathrm{N}-\mathrm{P})$ & $1.4,1.7$ & 2 \\
\hline 9 & Nodding $(\mathrm{N}-\mathrm{P})$ & 1.8 & 1 \\
\hline
\end{tabular}

Total number of non - verbal praise: 4 Total number of praise: 15

Note: $\mathrm{V}-\mathrm{P}$ : Verbal Praise

$\mathrm{N}-\mathrm{P}:$ Non verbal praise

Table 2 showed that male teacher only applied praise as a positive reinforcement. Verbal praise was used more than non verbal praise. It occurred 11times while non verbal praise merely 4 times. "Ok" was the verbal praise that commonly applied by male teacher, it appeared 4 times. On the other hand, male teacher mostly gave applause to praise the students non verbally. 
Negative Reinforcement

Table 3. Types and Frequency of Negative Reinforcement Used by a Male Teacher

\begin{tabular}{clcc}
\hline No & \multicolumn{1}{c}{ Findings } & Codes & $\begin{array}{c}\text { Frequencies of } \\
\text { Occurrence }\end{array}$ \\
\hline 1 & $\begin{array}{l}\text { Warming the student by looking at and } \\
\text { paying attention to what they have done }\end{array}$ & 4.8 & 1 \\
\hline 2 & Withdrawing certain image & 1.6 & 1 \\
\hline \multicolumn{3}{c}{ Total number of negative reinforcement } \\
\end{tabular}

Based on the above table, male teacher only employed negative reinforcement twice, during two sessions of teaching. They were in the form of warning the student by looking at and paying attention to what they have done, and withdrawing certain image. Each of them appeared once.

Table 4. Total Occurrences of Reinforcement Used by a Male Teacher (T1)

\begin{tabular}{ccc}
\hline No & Types of reinforcement used & Frequencies of occurrence \\
\hline 1 & Praise (Verbal and Non Verbal ) & 15 \\
2 & Negative reinforcement & 2 \\
\hline \multicolumn{2}{c}{ Total : 17 } \\
\hline
\end{tabular}

In conclusion, male teacher applied 15 praises (verbal and non - verbal) and 2 of negative reinforcement. Totally, there were 17 reinforcements applied by male teacher.

b) Types and Frequency of Reinforcement Used by the Female Teacher (T2) Positive Reinforcement

Table 5. Types and Frequency of Positive Reinforcement Used by a Female Teacher

\begin{tabular}{llcc}
\hline No & Positive Reinforcement & Codes & $\begin{array}{c}\text { Frequencies of } \\
\text { Occurrence }\end{array}$ \\
\hline 1 & Iya Bagus (V) & 3.9 & 1 \\
2 & Good (V) & $3.2,3.12,2.4,2.16$ & 4 \\
3 & Ya, Good (V) & $2.6,2.7,2.11,3.6,3.9$, & 7 \\
& & $3.10,3.13$ & 3 \\
4 & Ok, very good (V & $2.3,3.4,3.11$ & 3 \\
5 & Right & $2.8,2.9,2.13$ & 2 \\
6 & Yes, you right & $2.14,2.17$ & 2 \\
7 & Ya, very good & $2.12,2.15$ & 3 \\
8 & Good & $2.1,2.5,3.1$ & 25 \\
\hline \multicolumn{2}{c}{ Total number of verbal praise } \\
\hline 9 & Approaching to the & 2.10 & 2 \\
& students (N - V) & & 1 \\
\hline 10 & Smiling (N - V) & $2.4,2.16$ & \\
11 & Giving applause (N -V) & 2.6 & \\
& & &
\end{tabular}




\begin{tabular}{cc}
12 Nodding $(\mathrm{N}-\mathrm{V})$ & 3 \\
\hline Total number of non - verbal praise & 7 \\
\hline Total number of praise & 32 \\
\hline
\end{tabular}

The female teacher only applied praises including verbal and non - verbal praises. There were 32 numbers of praise applied by female teacher, which consisted of 25 verbal praises and 7 non - verbal praises. From verbal praise seen, "ya, good" was frequently used (7 occurrences). In term of non verbal praise, nodding was commonly used by the female teacher.

\section{Negative Reinforcement}

Table 6. Types and Frequency of Negative Reinforcement Used by a Female Teacher

\begin{tabular}{|c|c|c|c|}
\hline No & Findings & Codes & $\begin{array}{c}\text { Frequencies of } \\
\text { Occurrence }\end{array}$ \\
\hline 1 & $\begin{array}{l}\text { Warming the student by } \\
\text { looking at and paying } \\
\text { attention to what they have } \\
\text { done }\end{array}$ & $3.5,3.7,3.8,3.14$ & 4 \\
\hline 2 & Point reducing & 3.3 & 1 \\
\hline
\end{tabular}

In term of negative reinforcement, the female teacher employed negative reinforcements 5 times.

Table 7. Total Occurrences of Reinforcement Used by a Female Teacher (T2)

\begin{tabular}{clc}
\hline No & Types of reinforcement used & Frequencies of occurrence \\
& & \\
\hline 1 & Praise (Verbal and Non Verbal ) & 32 \\
2 & Negative reinforcement & 5 \\
\hline
\end{tabular}

Total : 37

In conclusion, a female teacher applied 32 praises (verbal and non - verbal) and 5 of negative reinforcement. Totally, there were 37 reinforcements applied by female teacher.

c) Comparison between Male and Female Teacher

In order to see how the male and female teacher differs in term of frequency of using reinforcement and they way of addressing reinforcement, as the following table:

\begin{tabular}{cccc}
\hline No & Subject & $\begin{array}{c}\text { Frequency of using } \\
\text { Reinforcement }\end{array}$ & Percentage \\
\hline 1 & Male teacher (T1) & 17 & $31.48 \%$ \\
2 & Female teacher (T2) & 37 & $68.52 \%$ \\
\hline \multicolumn{2}{c}{ Total } & 54 & $100 \%$ \\
\hline
\end{tabular}


1. Types and Frequency of Reinforcement Applied By Male Teacher (T1)

Based on findings, there were two types of reinforcement applied by the male teacher, namely praise (verbal and non - verbal) and negative reinforcement. Praise was the type of reinforcement that was commonly used with 15 occurrences. On the other hand, negative reinforcement only appeared twice. The following are details discussions on the types and frequency of reinforcement applied by male teacher (T1)

a) Praise

Praise was the common type of reinforcement employed by the first teacher. As has been showed previously, that praise appeared 15 times. It occurred 11times while non verbal praise merely 4 times. "Ok" was the verbal praise that commonly applied by male teacher, it appeared 4 times. He usually employed "Ok", when:

- The students answered the teacher's question correctly and performed something well.

Example 1:

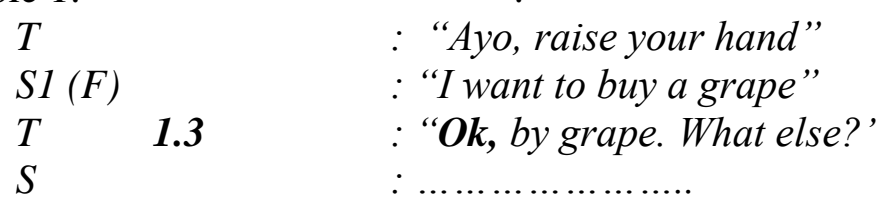

(Transcription 1, praise number 1.3)

In the first example, the teacher asked the student answered the teacher's question about how to respond a shopkeeper's statement. Because the student's answer was correct, the teacher praised her verbally by saying "ok". In the second example, the teacher praised the students verbally because they have performed a dialogue about shopping in front of the class properly. Therefore, the teacher gave them "ok".

The other verbal praise that was commonly applied was "ya". The male teacher usually applied verbal praise "ya" when:

Example1:

The students answered the teacher's question correctly.

$$
\begin{aligned}
& \text { T : "autumn. What is autumn?" } \\
& \text { S3 (M) : "musim gugur." } \\
& T \text { (4.1) : "Ya, all the leaves fall down. Gugur" }
\end{aligned}
$$

(Transcription 4, praise number 4.1)

In first example, it was clearly shown that the student was praised because has answered the question given correctly.

For non verbal - praise, the male teacher mostly gave applause to the students.

\section{Negative Reinforcement}

The application of negative reinforcement used by the male teacher was not as frequent as praise. Negative reinforcement was commonly used in order to motivate the students to be more active and being really involved in the process of teaching and learning. The following showed the example of negative reinforcement:

Example 1:

$T$ (1.6) : "next again. Cowoknya bagaimana? ......... Come on; now practice shopping in the bookshop!" (Looked and paid attention to a male student who was writing and discussed with his friend) 
It can be concluded from the observation that the male teacher merely used praise and negative reinforcement during two sessions of teaching. The teacher did not prepare something special to be used as reinforces. He just easily used anything available or anything that can be created by him such as praise and attention. It might be caused by the teacher's intention that wanted to make the students more independent and self motivated without being spoiled by reward or too many reinforcements.

b) Kinds of reinforcement and to whom they were addressed by male teacher

Based on the result of the observation showed that male teacher reinforced the students without regarding the students' gender. He just simply reinforced those who were active in the classroom. Reinforcement was given to both male and female students based on their participation in the classroom.

2. Types and Frequency of Reinforcement Applied By Female Teacher (T2)

It was absolutely the same with the male teacher; the female teacher only applied praise and negative reinforcement as well. The following are detail discussion about type and frequency of occurrence of each type of reinforcement used by the female teacher.

a) Praise

The female teacher applied praise including verbal and non - verbal during two sessions of teaching. Totally, there were 25 verbal praises and 11 non verbal praises. "ya good" was the verbal praise that was commonly used with seven occurrences. The teacher employed praise when:

- The students answered questions correctly

Example 1:

$$
\begin{aligned}
& T \quad: \text { "tempatnya dulu" } \\
& \text { S10 }(F) \quad: \text { "mall” } \\
& T \quad 2.7 \quad \text { : "ya good, mall. Selain itu } \\
& S \quad \text { :"market, shop". }
\end{aligned}
$$

(Transcription 2, praise number 2.7)

From the above example shows that the student has answered correctly the teacher's question, so that the teacher delivered as verbal praise " ya good"

- The students performed or did their job well

Example 1:

T : "kesempatan pertama siapa?"

Pair $2(F \& F):$ (come and perform in front of the class)

$T$ (2.11) : “ya, good. Coba lihat lagi percakapan yang tadi sudah mengerti

(Transcription 2 praise number 2.11)

Based on the result of the observation, the female teacher employed praise in the classroom as a media to create relax atmosphere a well.

In term of non verbal praise, the female teacher frequently gave smile to the students and approached them. 
Example 1:

S : "kasir."

T 2.10 : "Cashier in English. Apa biasanya di beli kalau shooping? (Approched a male student and talked to him)

(Transcription 2

praise

number

From the above example, the teacher showed her intimacy by approaching the students who were active in responding teacher's question. By approaching, the teacher automatically praised the students' response.

b) Negative reinforcement

There were two kinds of action took by the second teacher that were categorized into negative reinforcement, namely: warming the student by looking at and paying attention to what they have done and point reducing.

Example:

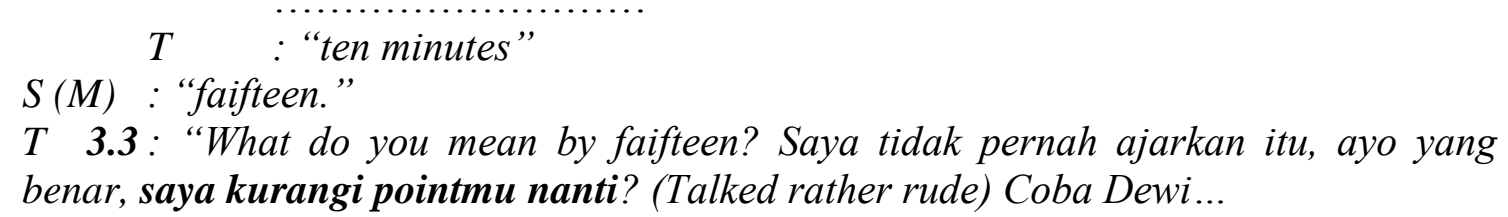

(Transcription 3, praise number 3.3)

During the process of teaching, some male students frequently responded teacher's question rather improper and the teacher response this improper by reducing his point. The result of the observation showed that female teacher applied more reinforcement than the male teacher. Female teacher delivered reinforcement in any chance so effective that the students feel comfort to study with her. Female teacher might be use reinforcement as a way to create close and warm atmosphere in the classroom that can make the students erased the gap between the teacher and the students.

c) Kinds of reinforcement and to whom they were addressed by female teacher Almost the same with male teacher, there was no gender consideration for female teacher in delivering reinforcement to the students. However, in delivering reinforcement in term of attention, female teacher dominantly gave it to the male students. It was caused by their characteristics as an active, aggressive, and competitive creature, but more due to their lower learning achievement and behaviors. 


\section{CONCLUSION}

Based on the above analysis, some conclusion can be drawn: male and female teacher are the absolutely the same in using the types of reinforcements in their teaching. They applied positive reinforcement in the form of praise (verbal and non verbal) and negative reinforcement.

Female teacher applied reinforcement more often than male teacher did. Female teacher applied it thirty seven times while male teacher only seven teen times. The use of more reinforcement, apparently, brought great effect toward the students' motivation. The students in female teacher's class were more active and the class was lived because the female teacher used reinforcement to maintain positive relationship with the students. While in male teacher's class, some students still looked doubt and afraid to show up because there was a little honor to students' work and there was no intimacy or closeness indicated by the male teacher.

Finally, in addressing reinforcements, male and female teacher did not use students' gender as a consideration, but more on students' participation. Through more attention given to male students, it was not an indication that the teachers treat male and female students differently. It was supported by the assumption that male students show a decreasing rate in achievement and behaviors. Therefore, the teacher tried to improve and make them balance with female students by giving attention.

\section{REFERENCES}

Bland, J. 2003. About Gender: Differences. Available at

Brophy,J.E. 1986. Teacher behavior and Its Effects. Available at http://www.nwrel.org/sepd/sirs/2/cu3.html.

Cotton, Katleen. 1988. The schooling Practice that matter Most. Available at http://www.nwrel.org/sepd/sirs/2/cu3.html.

Eckert, Penelope and McConnel-ginet, Sally. 2003. Language and Gender. New York: Cambridge University

Elliot, Stephen N., Kratochwill, Thomas R., Littlefield, John., Travers, John F. 1996. Educational Psychology Chicago: Brown \& Benchmark.

Lakoff, Robin. 1975. Language and Woman’s Place. New York: Harper \& Row.

Tannen, Deborah. No Year. You Just Don't Understand. Available at http://www.raysweb.net/poems/articles/tannen.html.

Tannen, Deborah. No Year. Feminine Focus / Masculine Focus. Available at http://www.usn.maine.edu/com/genderlect/tsld003.html.

Wardhaugh, Ronald. 2002. An Introduction to Sociolinguistics. Fourth Edition, UK Blackwell Publishers Ltd

Wolfgang, Charles H.2005. Reinforcement Theory. 